\title{
The Role of Collaborative Learning and Project Based Learning to Increase Students' Cognitive Levels in Science Literacy
}

\author{
Eka S. Sugianto ${ }^{1,2 *}$ \\ ${ }^{1}$ MAS Alkhairaat Kp. Jawa Tondano, Indonesia \\ ${ }^{2}$ Kantor Kementerian Agama Kabupaten Minahasa, Minahasa, Indonesia \\ *Corresponding author. Email: ekasugianto87@gmail.com
}

\begin{abstract}
Many studies have applied the Project-based learning method; many have also used collaborative learning in teachinglearning activities to increase students' skills. However, no study has yet combined collaborative learning with the project-based learning methods in a classroom to see if this method can increase student's cognitive levels and skills in literacy. This article seeks to discuss the application of collaborative learning by using project-based learning methods to increase students' thinking levels. The methodology that we use in this study is phenomenological study. The participants were teachers and students in MAS (Islamic Private Senior High School) Alkhairaat Kp. Jawa Tondano, Minahasa, North Sulawesi. Our research shows many students benefited positively through this method; however, we also found that some students with certain characteristics had bad experiences. Furthermore, this article presents the participants' problems and solutions when they have applied this combination approach in teaching-learning activities.
\end{abstract}

Keywords: Collaborative learning, Cognitive levels, Literacy, Project-based learning.

\section{INTRODUCTION}

The low cognitive level of students is one of the problems faced by teachers today. When compared with other developing countries, this can be seen in the latest PISA results, in which Indonesia is still in 74 out of 79 participating countries [1][2]. The Government has already made some efforts to overcome this problem by changing the curriculum continuously. They replaced the National Examination system into Computer-Based National Assessment by The Ministry of Education and Culture [3], and Indonesia Islamic School Competency Assessment by The Ministry of Religious Affairs [4].

The $21^{\text {st }}$ century requirement skills needed to increase students' cognitive levels are critical thinking, communication, creativity, and collaboration [5][6][7][8][9]. The main problem in learning activities is finding the proper method that may help students in mastering the four skills. A methodology that can be used to achieve creativity skills is project-based learning [10]. Project-based learning is also a popular learning method nowadays. It was applied in the classroom generally in Mathematics and Science subjects; [11], [12], [13], [14],
Language, Environmental and Vocational [15][16][17][18][19]. Project-based learning may also be used to produce a product [20]. Besides, to increase collaboration skills, we may employ collaborative learning [21].

Collaborative learning is an educational approach to teaching and learning that involves learners working together to solve a problem, complete a task, or create a product [22]. Collaborative learning combined with other methods may increase students' learning achievement positively. The strategies that can merge with collaborative learning are achievement motivation [23], mind mapping [24], the library of typical problem-based learning [25], and collaborative problem solving [26].

Many studies have been done to apply collaborative learning in increasing students' collaborating skills, and many studies have also been done to increase students' creativity by using project-based learning. However, no research combines these two in teaching-learning activities in a classroom. Based on the result of the research above, both collaborative learning and projectbased learning have many advantages in producing students with various skills. Therefore, we propose the 
application of collaborative learning in increasing students' cognitive levels in literacy by using projectbased learning. The research methodology we use is the phenomenological study based on Creswell's research [27]. Our study case is at MAS Alkhairaat Kp. Jawa Tondano in the $2^{\text {nd }}$ Semester of Academic Year 20202021. Beside producing products, this research also discusses how to increase students' cognitive levels in literacy with various characteristics. This article provides an alternative method for teachers in madrasahs, and the students' final products can utilize local wisdom and waste materials.

\section{METHODS}

\subsection{Research Design}

This research used a qualitative approach with a phenomenology study design. Phenomenology is the study of experience as it is concretely lived, which draws general structures or interpretations from this concrete particularity [28]. It is believed that this study was compatible in studying education [29][30]. The data was described in detail of the phenomenon being investigated. The description presented "how" the teachers and students experienced the teaching-learning process using collaborative learning and project-based learning [31].

The method of this phenomenological study was to gather and explore the experiences of 9 teachers and 15 students in MAS Alkhairaat Kp. Jawa Tondano, who practiced collaborative and project-based learning. The study, examined how these combinations increase students' cognitive levels in literacy [32] [33]. The research questions were expanded with some supporting questions using the basic principles of the phenomenological study [34][33]:

1. Research Question: How do collaborative learning and project-based learning increase students' cognitive level in MAS Alkhairaat Kp. Jawa Tondano?

2. SRQ1: In what way does this combination increase students' cognitive level?

3. SRQ2: How do students' characteristics affect the teaching-learning process?

4. SRQ3: How do students and teachers experience this teaching-learning activity in the classroom?

\subsection{Data Analysis}

Data were analyzed by using the Interpretative Phenomenology Analysis (IPA) since the study aims to find out how an individual interprets principal experiences in his/her life in a natural setting [35][34]. The stepwise technique was be used to analyze the data [34] [36]:
1. Describing the writer's personal experiences about the phenomena to be studied;

2. Listing some important statements;

3. Taking these statements and then group them into meaningful units or themes;

4. Writing the description of what teachers and students experience about the phenomenon;

5. Writing the description of how the experiences happen.

\section{RESULTS AND DISCUSSION}

The results of the study are related to the experiences of the fifteen participants who have different characteristics. It was found many positive experiences from them. It was also found a few bad experiences for some students with a particular characteristic. Eleven of the fifteen participants had positive experiences in this teaching-learning activity, and four had terrible experiences. This is due to their characteristics, not because of the learning system's weaknesses.

\subsection{Emerging Themes}

In order to present clearly analyzed data about the result study, it is described into several themes [37].

\subsubsection{Good experiences}

According to most participants, our learning approach could develop their self-management and sharpened their skills to work in a team both as a leader and a worker. In addition, they could also develop their self-potential by practicing their communication skills, feeling free to speak out their thoughts, listening to others both suggestions and criticism, working together as a team, suppressing their selfishness, and cultivating their sense of responsibility. Moreover, some students added that this learning approach could develop their critical thinking skills in producing a product. They added that this approach kept the knowledge in their minds longer than when the teacher just lectured in front of the class after taking an exam.

This result aligns with what UNESCO stated on its portal: collaborative learning was a relationship among learners that fostered positive interdependence, individual accountability, and interpersonal skills [5]. Another source of support is the resulting study [38] [39] that the students were responsible for one another's learning and their own.

Meanwhile, from the teachers' point of view, almost all the teachers had good experiences with this learning approach. In their opinion, students were more enthusiastic in teaching-learning activities, especially when it came to project production. They also get used to working in various backgrounds and helping each other so that they could succeed in finishing their project. This 
activity could strengthen their relationship. This is supported by some result studies [39][40][41]. The results of a mixed-methods analysis showed that if children received psychological support, they were likely to support others psychologically. Similarly, those who received concrete help tended to offer concrete help to others.

In addition to the benefits to the students, teachers also benefited from this approach. Some teachers claimed that this learning approach improved their teamwork skills with their colleagues in helping the students finish their projects. They learned how to think out of the box and expanded their view about teaching-learning activities. The most important thing from this learning approach application was that the students became creative to produce the product. At the end of the semester, they produced different products for each group, recycled the waste material, and utilized local wisdom by making flours with wildflowers.

\subsubsection{Bad experiences}

For the students who had bad experiences, they admitted that they could not adjust to the work rhythm of their friends. This happened because they were used to the teaching-learning activity, in which they needed to listen to the teacher's explanation. Some felt uncomfortable working in groups, and this was experienced by the student with an introverted personality. In addition, some students claimed that they were not suitable to work with specific students because they often argued. There were certain cases where students from non-madrasah schools had difficulty learning Arabic, so they needed to overcome this problem.

On the other hand, the teacher had a bad experience when students did not understand the material because they ignored the teacher's explanation. They were not actively involved in group work. The teachers also observed that some students were feeling envious because he/she felt that all the work was burdened on him/her. This was a critical moment for the teacher to redirect the students to reduce clashes in the group.

\subsection{Problems}

- Some students needed to adapt with the team's speed.

- Some quiet students felt uncomfortable.

- Some students argued with each other.

- Someone tried to take over the team.

- Not all of the students could get the point of the lesson, especially for whom those who do not actively work in a team.

- Feelings of envy.

\subsection{Solutions}

- Teachers motivated students.

- Teachers asked students to discuss a lot.

- Teachers always guided students.

- Teachers took a humanist approach to overcome students who did not want to work in a team.

- Teachers told them some good stories about Prophet Muhammad's friends and previous famous Islamic scholars. It was about how they treated their teacher when they wanted to learn something.

- For a specific student who had certain problems, teachers gave them tutoring time outside of class hours.

- $\quad$ Teachers provided material outside of the textbooks to students who had difficulty in understanding the foreign languages, especially Arabic.

- For the students who mastered all the topics and beyond from their friends, the teachers gave them more challenging tasks.

Based on the description above, the combination of collaborative learning and project-based learning could increase student's cognitive levels in literacy by applying the theory to practical situations. This learning seemed suitable to be applied in madrasahs if teachers wanted to increase madrasah students' cognitive levels in literacy and develop their $21^{\text {st }}$ century required skills. Referring to Pearlman's statements that the new work environment requires responsibility and the ability to manage the interpersonal and project-management skills needed for teamwork and leadership, project-based learning was designed to work as the student-as-workers setting. In this situation, they learned skills, such as collaboration, critical thinking, creativity, and written and oral communication skills [42].

The theories were reinforced [43][44] that there were four reasons why the collaborative learning approach was suitable to be applied in learning; they were (1) collaborative learning was the essence of learning, (2) to actualize the learning rights of every student without exception, there was no method other than mutual learning among students through collaborative learning, (3) showing that small group collaborative learning was a vehicle to improve students' low academic abilities, and (4) collaborative learning could also guarantee students with higher academic abilities. However, some requirements must be met. Collaborative learning had to include challenges to higher-level materials, which were called "jumping tasks."

Besides, the collaborative learning was an umbrella term for various educational approaches involving a joint intellectual effort by students or students and teachers together [45]. It can be said that teachers could use various learning methods with collaborative learning, and in this study, collaborative learning was combined with project-based learning. It is believed that this study 
still had some flaws, so some recommendations were needed for further research, that is:

1. Doing research with some madrasahs as the population or sample to apply this approach to seek the effectiveness of this combination approach.

2. Designing some more complex projects so it can make students challenge themselves.

3. Designing a project that deals with the 4.0 revolution era and upcoming 5.0 era, so both teachers and students can break their limits.

4. Doing quantitative research to present specific data to show the effectiveness of this approach in increasing the students' cognitive levels in literacy make students challenge themselves.

5. Designing a project that deals with the 4.0 revolution era and upcoming 5.0 era, so both teachers and students can break their limits.

6. Doing quantitative research to present specific data to show the effectiveness of this approach in increasing the students' cognitive levels.

\section{CONCLUSION}

Based on the study we have done with all participants. We conclude that combining collaborative learning and project-based learning gives more good experiences than bad experiences. Even though there are still some problems in the application, teachers can fix that by finding solutions to overcome them. From this study, we can also notice that this approach succeeded in increasing students' cognitive levels in literacy. Students can improve their four skills: critical thinking, communication, creativity, and collaboration. So, we would like to claim that collaborative learning is an appropriate approach to be applied in madrasah if we want to improve the students' quality of thinking. Significantly when we adjusted, it assisted with projectbased learning.

\section{AUTHOR CONTRIBUTIONS}

All author conceived and designed this study. All author contributed to the process of revising the manuscript, and at the end all author has approved the final version of this manuscript.

\section{ACKNOWLEDGMENTS}

All praise and gratitude go to the Almighty God, Allah SWT. The highest appreciation goes to Dr. Nina Fitriyati who has guided the writing of good articles. Special thanks also to Caroline Juhyung Kim for the language supervision.

\section{REFERENCES}

[1] OECD, PISA 2018 Results, oecd.org, 1 (2019), www.oecd.org/about/publishing/corrigenda.htm.

[2] L. Hewi, M. Shaleh, Refleksi Hasil PISA (The Programme for International Student Assesment): Upaya Perbaikan Bertumpu Pada Pendidikan Anak Usia Dini), Jurnal Golden Age, 04(1) (2020) 30-41.

[3] L. Kemendikbud, Penghapusan Sistem Ujian Nasional, 2020 , https://pmp.dikdasmen.kemdikbud.go.id/beritalpmp.

[4] AKMI Kemenag, 2021, https://akmi.kemenag.go.id/.

[5] UNESCO, 21st Century Required Skills, 2000, https://en.unesco.org/.

[6] Wikipedia, 21st Century Skills, 2020.

[7] D.V.J. Bell, Twenty-first century education: Transformative education for sustainability and responsible citizenship, Journal of Teacher Education for Sustainability 18(1) (2016) 48-56 DOI: $10.1515 /$ jtes-2016-0004

[8] S. Zubaidah, Keterampilan Abad Ke-21: Keterampilan Yang Diajarkan Melalui Pembelajaran, Seminar Nasional Pendidikan Program Studi Pendidikan Biologi STKIP Persada Khatulistiwa Sintang, Kalimantan Barat, 2016, https://www.researchgate.net/publication/3180136 27.

[9] G.S. Subia, M.C. Marcos, L.E. Pascual, A.V. Tomas, M. M. Liangco, Cognitive Levels as Measure of Higher-Order Thinking Skills in Senior High School Mathematics of Science, Technology, Engineering and Mathematics (STEM) Graduates, Technology Reports of Kansai University, 62(03) (2020) 261-268.

[10] W. Sumarni, The Strengths and Weaknesses of the Implementation of Project Based Learning: A Review, International Journal of Science and Research, 4(3) (2015) 478-484.

[11] I. B. Siwa, I. W. Muderawan, I. N. Tika, Pengaruh Pembelajaran Berbasis Proyek Dalam Pembelajaran Kimia Terhadap Keterampilan Proses Sains Ditinjau Dari Gaya Kognitif Siswa, Jurnal Pendidikan dan Pembelajaran IPA Indonesia, 3(1) (2013)

[12] L.R. Emery, S.L. Morgan, The application of project-based learning in bioinformatics training, PLoS computational biology, 13(8) (2017) e1005620. DOI: 10.1371/journal.pcbi.1005620. 
[13] C. Carnawi, S. Sudarmin, N. Wijayati, Application of Project Based Learning (PBL) Model for Materials of Salt Hydrolysis to Encourage Students' Entrepreneurship Behaviour, International Journal of Active Learning, 2 (1) (2017) 50-58.

[14] S. Masfuah, F. Fakhriyah, S. Masfuah, Developing The Understanding of Scientific Concept Based on the Aspect of Science Literacy For Students of Elementary School Education Program through the Application of Project Based Learning, Unnes Science Education Journal, 6(3) (2017) 1708-1716, URL: http://journal.unnes.ac.id/sju/index.php/usej

[15] F.N. Kurniawati, S. Susanto, A. Munir, Promoting Students' Communication Skill through the Application of Project Based Learning, Linguistic, English Education and Art (LEEA) Journal, 3(1), (2019) 26-44. DOI:10.31539/leea.v3i1.970

[16] Mislena, Erlina, H.W. Anggraini, The Application of Project Based Learning $(\mathrm{Pbl})$ through Storyboard to Improve Reading Achievement of The 10th Grade Students, 4th Sriwijaya University Learning and Education International Conference, 2020, pp. $395-401$.

[17] R. Untari, W. Kamdi, Dardiri, S. Hadi, D. Nurhadi, The Development and Application of Interactive Multimedia in Project-Based Learning to Enhance Students' Achievement for 2D Animation Making, Journal of Emerging Technologies in Learning, 15 (16) (2020) 17-30.

[18] N. Ain Zulhaimi, N. Shafiekah Sapan, S. Aishah Ramli, S. Nurul Aishah Abdul Hamid, S. Katijah Johari, Application of Project-Based Learning in Enhancing Solid Waste Management and Awareness, International Journal of Advanced Research in Education and Society, 3(1), (2021). URL: http://myjms.mohe.gov.my/index.php/ijares

[19] S. Munawaroh, I.S. Suja'i, D.S.N. Afifah, I. M. Putri, Students' Creativity in Project Based Learning, Proceedings of the 2nd Annual Conference on Social Science and Humanities (ANCOSH 2020), Advances in Social Science, Education and Humanities Research, 2021, 542, pp. 376-379.

[20] Y.C. Gai Mali, Project-Based Learning in Indonesian EFL Classrooms: from Theory to Practice, Indonesian Journal of English Education 3(1) (2016) 89-105. DOI: 10.15408/ijee.v3i1.2651.

[21] M. Laal and M. Laal, Collaborative learning: What is it?, Procedia-Social and Behavioral Sciences, 31 (2012) 491-495. DOI: 10.1016/j.sbspro.2011.12.092.
[22] H. Srinivas, Collaborative Learning, 2011, URL: http://www.gdrc.org/kmgmt/c-learn/.

[23] N. Fazriyah, Pengaruh Model Pembelajaran Terpadu Terhadap Hasil Belajar IPA, Jurnal Mahasiswa Teknologi Pendidikan, 1(1) (2017) 6582. DOI: 10.23969/jp.v1i1.224.

[24] N. Nyoman, Pengaruh Model Pembelajaran Kolaboratif Hasil Belajar Ipa, Jurnal Ilmu Pendidikan Profesi Guru, 2(2) (2019) 125-136.

[25] S. Strauß, Developing a Library of Typical Problems during Collaborative Learning in Online Courses, ISLS, 2018.

[26] C.T. University, Metode Pembelajaran Collaborative Problem Solving Strategi Meningkatkan Pemahaman dalam Proses Pembelajaran Mahasiswa, 2019. URL: https://ctle.telkomuniversity.ac.id/docs/teachinresources/science-maths-and-technology.

[27] J.W. Creswell, Qualitative Inquiry and Research Design: Choosing Among Five Approaches, 16(4) (2015).

[28] N. Friesen, Phenomenology and Education : Researching Pedagogical Experience, 2021, URL: https://www.researchgate.net/publication/3492559 39.

[29] A. Alase, The Interpretative Phenomenological Analysis (IPA): A Guide to a Good Qualitative Research Approach, International Journal of Education and Literacy Studies, 5(2) (2017) 9-19, DOI:10.7575/aiac.ijels.v.5n.2p.9.

[30] Helaluddin, Mengenal Lebih Dekat dengan Pendekatan Fenomenologi: Sebuah Penelitian Kualitatif, 2018, URL: https://www.researchgate.net/publication/3236004 31.

[31] K. Eddles-Hirsch, Phenomenology and educational research, International Journal of Advanced Research, 3(8) (2015) 251-260.

[32] D. E. Polkinghorne, Phenomenological research methods, Phenomenological Research Methods. In: Valle R.S., Halling S. (eds), ExistentialPhenomenological Perspectives in Psychology, Springer, Boston, MA, 1989, DOI: https://doi.org/10.1007/978-1-4615-6989-3_3.

[33] N. Greening, Phenomenological Research Methodology, Scientific Research Journal, 7(5) (2019) 88-92. DOI: 10.31364/scirj/v7.i5.2019.p0519656.

[34] C. Moustakas, Phenomenological Research Methods. Thousand Oaks: CA: Sage, 1994. 
[35] P. Ananda, L. Kahija, F. Yohanis, Mengajar Sembari Belajar: Sebuah Interpretative Phenomenological Analysis Tentang Pengalaman Pengajar Muda Gerakan Indonesia Mengajar, Empati, 7(3) (2018) 186-196.

[36] M. D. Vagle, Phenomenological Research Methodology, Crafting Phenomenol Research., (2019) 71-84. DOI: 10.4324/9781315173474-9.

[37] J. P. Williams, Emergent themes, 2008, URL: https://www.researchgate.net/publication/2652801 67.

[38] D. K. Khosa, S. Volet, Productive group engagement in cognitive activity and metacognitive regulation during collaborative learning: can it explain differences in students ' conceptual understanding ?, Metacognition and Learning, 9(3) (2014) 287-307. DOI: 10.1007/s11409-014-9117-z.

[39] A. La Hanisi, R. Risdiany, Y. Dwi Utami, D. Sulisworo, The use of WhatsApp in collaborative learning to improve English teaching and learning process, International Journal of Research Studies in Educational Technology, 7(1) (2018) 29-35. DOI: 10.5861/ijrset.2018.3004.

[40] D. Yasseri, P. M. Finley, B. E. Mayfield, D. W. Davis, P. Thompson, J. S. Vogler, The Hard Work of Soft Skills: Augmenting the Project-Based Learning Experience with Interdisciplinary Teamwork, Instructional Science, 46(3) (2018) 457488 .

[41] M. E. Gredler, Learning and Instruction, Teori dan Aplikasi Edisi Keenam, Sixth Edit. Jakarta: Kencana, 2011.

[42] B. Pearlman, Project-Based Learning, edutopia.org, 2002. URL: https://www.edutopia.org/bobpearlman-project-based-learning

[43] M. Kageto, S. Sato, G. Kirkpatrick, How to Cultivate Global Competencies Through ProjectBased Collaborative Learning in University Students. In J. Viteli \& M. Leikomaa (Eds.), Proceedings EdMedia World Conference Education Media Technology, Tampere, Finland, Association for the Advancement of Computing in Education (AACE), 2014, pp. 1141-1146, URL: https://www.learntechlib.org/p/147636/.

[44] S. Asari, Sharing and Jumping Task In Collaborative Teaching and Learning Process, Didakt Jurnal Pemikiran Pendidikan, 23(2) (2017) 184-188. DOI: 10.30587/didaktika.v23i2.28.

[45] B. L. Smith, J. T. MacGregor, What is Collaborative Learning?, Towards the Virtual University: International Online Learning Perspectives, 1992, pp. 217-232, URL: https://www.researchgate.net/publication/2422824 75 